\title{
IS THERE A LATIN AMERICAN CHILD MIGRATION LAW? AN ANALYSIS OF THE 'ADVISORY OPINION N. 21 ON THE RIGHTS OF CHILD MIGRANTS' RENDERED BY THE INTER-AMERICAN COURT OF HUMAN RIGHTS
}

\author{
EXISTE UM DIREITO LATINO-AMERICANO PARA CRIANÇAS \\ MIGRANTES? UMA ANÁLISE DA 'OPINIÃO CONSULTIVA N. 21 \\ SOBRE O DIREITO DAS CRIANÇAS MIGRANTES' DA CORTE \\ INTERAMERICANA DE DIREITOS HUMANOS
}

Tatiana A F R Cardoso Squeff'

Marcia Leonora S. R. Orlandini ${ }^{2}$

\begin{abstract}
In 2014, in response to the request of the Southern Cone countries, the Inter-American Court of Human Rights issued an Advisory Opinion on the rights of migrant children in an attempt to emphasize the minimum guarantees that the countries of the region should grant to this category of migrant, especially considering their hypervulnerability when compared to adult migrants. Such request, made in the light of the growing migratory flow of unaccompanied minors in the Americas, has led the Court to point to a number of rights that should be particularly guaranteed, such as the right to seek and receive asylum, non-criminalization, non-detention, and non-return of minors, culminating in the design of what can be considered as a LatinAmerican Child Migration Law, being it why the present research is deemed relevant, as it emphasizes what would be the bases of this Law. For that matter, a descriptive and exploratory research was conducted, parting from an inductive method through a detailed study of the Advisory Opinion no. 21/14, and, thus, primarily using the documental technique, chosen qualitatively.
\end{abstract}

KEYWORDS: Migration. Children. Inter-American Court of human Rights. Advisory Opinion no. 21/14.

1 Professora Adjunta de Direito Internacional da Universidade Federal de Uberlândia. Doutora em Direito Internacional pela UFRGS, com período sanduíche na University of Ottawa. Mestre em Direito Público pela Unisinos, com fomento CAPES e DFAIT. Pós-graduada em Relaçóes Internacionais pela UFRGS/ PPGEEI, em Direito Internacional pela UFRGS/PPGD. tatiafrcardoso@gmail.com

2 Doutoranda em Direito Internacional pela Universidad de Valencia (ES). Mestre em Direito pela PUCSP. Especialista em Filosofia pela UFU. Graduada em Direito pela UFMG. Professora adjunta do curso de Direito da Universidade Federal de Uberlândia, onde coordena a Clínica de Enfrentamento ao Trabalho Escravo.marcialeonora@hotmail.com 
RESUMO: Em 2014, em resposta à solicitaçăo dos países do Cone Sul, a Corte Interamericana de Direitos Humanos emitiu um parecer consultivo acerca dos direitos das crianças migrantes, na tentativa de ressaltar quais seriam as garantias mínimas que os países da regiâo deveriam conferir para essa categoria de migrante, considerando especialmente a sua hipervulnerabilidade quando em comparaçâo aos migrantes adultos. Tal solicitaçăo, feita à luz do crescente fluxo migratório de menores desacompanhados nas Américas, conduziu à Corte a apontar uma série de direitos que deveriam ser particularmente garantidos, como o direito de de buscar e receber asilo, a năo-criminalizaçăo, a năo-detençăo e a năo-devoluçăo de menores, terminando por arquitetar o que poderia ser conceituado como um direito latino-americano para crianças migrantes, estando nesse aspecto a relevância do presente estudo, justamente por ressaltar quais seriam as bases deste direito. Para tanto, conduziu-se uma pesquisa descritiva e exploratória, através do método indutivo, partindo particularmente do estudo da Opiniăo Consultiva n. 21/14, motivo pelo qual a técnica utilizada para as fontes de pesquisa foi, sobretudo, a documental, escolhida qualitativamente.

Palavras-chave: Migraçăo. Criança. Corte Interamericana de Direitos Humanos. Opiniăo Consultiva n. 21/14.

\section{INTRODUCTION}

In June 2018, a series of news broadcasted a sad reality in the Unites States: the separation of nearly 2000 child migrants from their parents at the US-Mexico border (BBC, 2018) and their subsequent incarceration/institutionalization (ARNOLD, 2018) - a measure that has been used in that country to deal with uprising numbers of child migration especially since the beginning of this decade (ROSENBLUM, 2015). "In Europe, countries generally detain migrants much less frequently than in the United States. Authorities detain children only if there are special facilities in place, only after they try less-coercive measures and only if the separation is in the best interests of the child" - policies that not only are legally allowed, but that have also been roughening due to emerging far-right political movement endorsements and proposals, as in Poland, Hungary and France (SHINKMAN, 2018).

Such measures publicize the rising number of children crossing borders and requesting asylum. In accordance to the United Nations, as cited by the Inter-American Court of Human Rights, out of the 61,617,229 migrants of the Americas in 2013, "6,817,466 were under 19 years of age"; and "more than 25,300 individual requests for asylum were made for children who were unaccompanied or separated in 77 countries around the world" (IACHR, 2014, Para. 34). Beyond that, such measures also expose a questionable way of treating migrants, especially when involving children, who should be most protected simply due to their vulnerable condition of not being fully grown (IACHR, 2014, Paras. 56, 66 and 114).

Thus, a question that arises from this scenario is whether there are specific rules applicable to the protection of child migrants under international law. Despite of the fact that the 1989 Child Convention (UN, 2004) has been ratified by almost all United Nations (UN) countries, there is nothing within such text that is directly applicable to 
migration influxes, therefore, being it applicable only on a general basis, to interpret other [specific] rules. On the same token, regional human rights and refugee law instruments do not prescribe specific rules to the treatment of child migrants, denouncing the lack of proper rules to regulate the conduct of states when dealing with these influxes, leaving more space to state interpretation.

Because of this, Argentina, Brazil, Paraguay and Uruguay requested an Advisory Opinion to the Inter-American Court of Human Rights (IACHR) in 2011 intended to define the obligations that Organization of American States (OAS) State-Parties have regarding their migratory policies, especially on child migrants. Thus, after deciding to deliver an opinion ${ }^{3}$, the Court enumerated some maxims that should guide the Organization's members ${ }^{4}$ through the processing of children who seek asylum within their boundaries, as the right to seek and be granted asylum, the principle of non-criminalization and non- detention, and the reaffirmation of the non-refoulement principle.

Therefore, by doing so, the Court pointed out what shall be considered the InterAmerican standards of child migration law, which may serve as a basis for intra-region countries (such as the Unites States) and as an example to other states (as those in Europe) to deal with such misfortune, materializing a new dialogue route in international law, that is, from South to North ${ }^{5}$, which shall be discussed in the following topics through a descriptive and exploratory research, parting from an inductive method through a detailed study of the before mentioned Advisory Opinion - the 'OC 21 ' of 2014, and, thus, primarily using the documental technique, chosen qualitatively.

\section{FIRST MAXIM OF THE LATIN-AMERICAN CHILD MIGRATION LAW: RIGHT TO SEEK AND BE GRANTED ASYLUM}

The right to seek and be granted asylum is the basis of migration in Latin-America, being prescribed by article $22(7)^{6}$ of the American Convention of Human Rights (OAS, 1969) and article XXVII of the American Declaration of the Rights and Duties of Man ${ }^{7}$ (OAS, 1948). This view is deemed important, first because it is considered a human right apart from the state-centric idea of fiercely controlling its borders; and second,

3 "On numerous occasions, this Court has established that compliance with the regulatory requirements to submit a request for an advisory opinion does not mean that the Court is obliged to respond to it" (IACHR, 2014, Para. 25).

4 "Given the broad scope of the Court's advisory function, which, as previously indicated, encompasses not only the States Parties to the American Convention (supra para. 23), everything indicated in this Advisory Opinion also has legal relevance for all the OAS Member States that have adopted the American Declaration, irrespective of whether they have ratified the American Convention, 26 as well as for the organs of the OAS whose sphere of competence relates to the matter that is the subject of the request" (IACHR, 2014, Para. 32).

5 It is imperative to highlight that United States is considered to be a Global North country, despite of the fact that is situated in the Americas. See GROSFOGUEL, 2002.

6 Article 22. Freedom of Movement and Residence [...] 7. Every person has the right to seek and be granted asylum in a foreign territory, in accordance with the legislation of the state and international conventions, in the event he is being pursued for political offenses or related common crimes (IACHR, 2014, Para. 72; OAS, 1969).

7 Article XXVII. Right of asylum Every person has the right, in case of pursuit not resulting from ordinary crimes, to seek and receive asylum in foreign territory, in accordance with the laws of each country and with international agreements (IACHR, 2014, Para. 72; OAS, 1948). 
because it affirms the need of not only of asking for a formal asilee status, but also receiving it from a country.

Different from other interpretations ${ }^{8}$, the Inter-American Court has stated that these legal basis "have enshrined the subjective right of all persons, including children, to seek and receive asylum, thereby overcoming the historical understanding of this mechanism as a 'mere State prerogative'", considering it as a human right, part of men intrinsic characteristics and from which it cannot apart themselves from.

By all means, it should be said that in Latin-America, the idea of asylum started from the very limited idea of protecting a migrant who was being personally persecuted due to a political crime. However, it has been expanded since the end of the Second World War, as the Court explains:

It should be recalled that although the concept of asylum was initially rooted in the notion of the Latin American tradition of asylum, which consisted of diplomatic and territorial asylum and non-extradition for political motives or offenses, the truth is that, following the adoption of the 1951 Convention relating to the Status of Refugee and its 1967 Protocol, the mechanism of asylum assumed a specific form and modality at the universal level: that of the status of refugee (IACHR, 2014, Para. 74).

Due to this broadening, within Latin-America, asylum contemplates not only the typical refugee, but also those people that traditionally ran from individual political persecution and all other people who have left "their countries because their life, safety or freedom have been threatened by generalized violence, foreign aggression, internal conflicts, massive violation of human rights or other circumstances which have seriously disturbed public order", in the terms of the 1984 OAS Cartagena Declaration (IACHR, 2014, Para. 76; OAS, 1984); and even those who fled because their country fails to overturn "the challenges of protection derived from other displacement patterns that currently take place" (IACHR, 2014, Para. 79).

As a result, since having the status of refugee declared is considered a right that individuals intrinsically have by simply meeting its elements9, it should be extended to all other asylum categories. Besides, since "children enjoy the same rights as adults and also possess additional rights" (IACHR, 2014, Para. 66), they may contemplate specific reasons to fleeing in regard to their "age and gender", as the Court stated:

[I]t should be recognized that the elements of the definition of refugee were traditionally interpreted based on the experiences of adults or persons over 18 years of age. Hence, in view of the fact that children are entitled to the right to seek and receive asylum and may, in consequence, submit applications for recognition of refugee status in their own capacity, whether or not they are accompanied, the elements of the definition should be interpreted taking into account the specific forms that child persecution may adopt, such as recruitment, trafficking, and female genital mutilation, as well as the way in which they may experience these

8 See the discussions on the A, B \& C v. Ireland and the J.R. and others v. Greece judgments before the European Court the Human Rights (DEMBOUR, 2015).

9 "The Court has noted that "[a]ccording to the 1951 Convention, a person is a refugee as soon as he meets the requirements set out in the definition, which necessarily occurs before his refugee status has been decided formally. Thus, the recognition of the refugee status of a person is of a declarative rather than a constitutive nature" (IACHR, 2014, fn. 416). 
situations. [...]Moreover, in addition to the traditional reasons for seeking refuge mentioned above, it is pertinent to be aware of the new factors that lead individuals and, in particular children, to be forcibly displaced from their countries of origin, among which transnational organized crime and the violence associated with the actions of non-State groups stand out (IACHR, 2014, Para. 80).

Not only that, those non-limited "extra" categories must be identified by the States under the penalty of infringing the due diligence principle, since the provision of adequate and individualized treatment to child migrants is considered a positive obligation of the States by the Court.10

In this sense, the Court not only established that children may have different/extra categories of persecution amounting to asylum, but also that "States are obliged to identify foreign children who require international protection within their jurisdictions, either as refugees or of another type" (IACHR, 2014, Para. 82), and, if they meet such elements, they must be declared asilees as it is their rights as humans (instead of a prerogative of the State to concede it).

Moreover, following such line of thought, the Court not only asserted the existence of a (human) right to be given to any child in a migratory context, but it has consequently created an opposite duty to States in the region, which is the duty to grant asylum if one who requests it plainly fulfills its requirements. This outcome is rather new in general migration law as the (human) right to migrate was not considered as being binomial, but a one-way right due to the possibility of countries to deny entrance to anyone in light of its sovereign right to choose those who may enter their borders.

\section{SECOND MAXIM OF THE LATIN-AMERICAN CHILD MIGRATION LAW: THE PRINCIPLES OF NON-CRIMINALIZATION AND NON-DETENTION}

The second axiom of the Latin-American migration law relates to the recognition and concurrent application of two principles, which are non-criminalization and non-detention. And to discuss such maxim in the framework of child migration, there are two different contexts that must be analyzed: those involving unaccompanied children, and those that encompass children that are accompanied by their parents/ legal guardian/relatives.

First and foremost, it should be stated that the non-detention principle relates to the general impossibility of one being arrested simply because of its illegal migratory status. In accordance to the Court, one cannot be deprived of its personal liberty, being, thus, "unable to leave or abandon at will the place or establishment where she or he has been placed" (IACHR, 2014, Para. 145) "including, though not limited to, prisons or purpose-built detention, closed reception or holding centres or facilities" (IACHR,

10 "In order to comply with international undertakings, States are obliged to identify foreign children who require international protection within their jurisdictions, either as refugees or of another type, through an initial evaluation with guarantees of safety and confidentiality, in order to provide them with the adequate and individualized treatment required by means of special measures of protection. The Court considers that the establishment of procedures to identify the needs for protection is a positive obligation of the States and failing to institute them represents a lack of due diligence" (IACHR, 2014, Para. 82). 
2014, Para. 146), in light of articles 7 of the American Convention of Human Rights11 and XXV of the American Declaration of the Rights and Duties of Man12. After all, migrants' liberty deprivation is deemed arbitrary13.

Such principle derives from another one, i.e. the principle of non-criminalization of migrants (also known as 'crimmigration'14), whose bases ascertain that no one shall be considered a criminal just because he/she is immigrating to another nation without complying with the requirements of domestic legislation on the matter 15, particularly due to the unnecessary/arbitrary restrictions one may suffer in its human rights, "as the right to seek and receive asylum" by reason of persecution (IACHR, 2014, Para. 146).

However, as a last resort, for founded precautionary purposes (IACHR, 2014, Para. 148), migrants may be imprisoned (IACHR, 2014, Para. 144). In accordance to the Court,

[...] the detention of an individual owing to failure to comply with the immigration laws should never be for punitive purposes so that the measures of deprivation of liberty should only be used when they are necessary and proportionate in a specific case in order to ensure the appearance of the person at the immigration proceedings or to guarantee the implementation of a deportation order and only for the shortest time possible (IACHR, 2014, Para. 151).

Not only that, even though it was not mentioned by the Court in the Advisory Opinion under analysis, for the Inter-American Commission of Human Rights (IACmHR), detention of illegal migrants happens if the

[...] [g]rounds for detention [are] clearly and exhaustively defined and the legality of detention [is] open for challenge before a court and regular review within fixed time limits. Established time limits for judicial review must even stand in "emergency situations" when an exceptionally large number of undocumented immigrants enter the territory of a State. Provisions should always be made to render detention unlawful if the obstacle for identifying immigrants in an irregular situation or carrying out removal from the territory does not lie within their sphere (IACmHR, 2015).

Besides, such extraordinary deprivation of liberty it is only applicable to adult migrants, meaning that child migrants ${ }^{16}$ are exempt from such possibility, especially if not accompanied by anyone because of their ultra-vulnerability status ${ }^{17}$. Says the Court:

11 Article 7. Right to Personal Liberty 1. Every person has the right to personal liberty and security. [...] 3. No one shall be subject to arbitrary arrest or imprisonment. [...] (IACHR, 2014, fn. 258; OAS, 1969).

12 Article XXV. Right of protection from arbitrary arrest (IACHR, 2014, fn. 262; OAS, 1948).

13 "[D]eprivation of liberty as a penalty or a punitive sanction in the area of immigration control [...], in accordance with the jurisprudence of this Court, must be regarded arbitrary and thus contrary to the Convention and American Declaration" (IACHR, 2014, Para. 147).

14 For a debate on the term, cf. ARRIAGA, 2016, p. 805-812; and STUMPF, 2006, p. 367-370.

15 "The Special Rapporteur of the United Nations on the Human Rights of Migrants has recommended that '[d]etention of migrants on the ground of their irregular status should under no circumstance be of punitive nature' [...]. Similarly, the Working Group on Arbitrary Detention has affirmed that 'criminalizing illegal entry into a country exceeds the legitimate interest of States to control and regulate illegal immigration and leads to unnecessary detention' (IACHR, 2014, fn. 271).

16 For the Court, a child migrant is "every human being below the age of eighteen years unless, under the law applicable to the child, majority is attained earlier" (IACHR, 2014, Para. 49).

17 "[T]he Court stresses that the situation of being unaccompanied or separated exposes children to 'various 
On the grounds that the offenses concerning the entry or stay in one country may not, under any circumstances, have the same or similar consequences to those derived from the commission of a crime, and in recalling the different procedural purposes between migration and criminal proceedings, the Court considers that the principle of ultima ratio of the imprisonment of children is not [applicable] in the arena of [illegal] immigration proceedings (IACHR, 2014, Para. 150).

Yet, it should be stressed that the Court does not defend that children should never be imprisoned ${ }^{18}$. In light of the Court's reasoning regarding crimes prescribed by law (with the exception of illegal migration as discussed supra), if imprisonment is used for the shortest period of time possible and as a measure of last resort, they may be applicable by local tribunals ${ }^{19}$. More specifically, the Court recognized that,

[...] in relation to the right to personal liberty in cases concerning juveniles in conflict with the law, that the deprivation of liberty, either on remand or as a punishment, constitutes a measure of last resort that should be used, when appropriate, for the shortest appropriate period of time, since the purpose of criminal proceedings in the case of children is fundamentally pedagogical. Thus, deprivation of liberty in the context of juvenile criminal justice must respect the principles of legality, exceptionality, and the shortest appropriate period of time. Moreover, the exceptional nature of detention on remand operates more strictly because the rule should be liberty and, if the need for a precautionary measure is verified, the application of alternative measures should be given priority (IACHR, 2014, Para. 149).

Hence, regarding the incarceration of children in Latin America, such penalty should only be applied if no other measure is feasible and for pedagogical purposes only, meaning that such imprisonment should be the shortest as possible and apart from adults20, but never applicable to child unlawful immigration. After all, it may only happen if prescribed by law, excluding the possibility of illegal cross-border to be considered a crime punishable by deprivation of liberty, even if the OAS MemberState establishes so in its local statutes.

risks that affect their life, survival and development such as trafficking for purposes of sexual or other exploitation or involvement in criminal activities which could result in harm to the child, or in extreme cases, in death,' especially in those countries or regions where organized crime is present. In particular, children who are unaccompanied or separated from their family and who are away from their country of origin are particularly vulnerable to child trafficking, exploitation and abuse. The Court recognizes that female children may be even more vulnerable to trafficking, especially for purposes of sexual and labor exploitation" (IACHR, 2014, Paras. 90-91).

18 In name of the children's best interests, there are eve, some criteria that national courts should assess for their detention, which are: "(i) whether the objective of the measures that restrict or deprive liberty are compatible with the Convention; (ii) whether the measures adopted are appropriate to achieve the objective sought; (iii) whether they are necessary, and (iv) whether the measures are strictly proportionate, so that the sacrifice inherent in the restriction of the right to liberty is not exaggerated or excessive in relation to the advantages obtained from this restriction and the achievement of the objective sought" (IACHR, 2014, Para. 153).

19 "Article 37(b) of the Convention on the Rights of the Child stipulates that the States Parties must ensure that: No child shall be deprived of his or her liberty unlawfully or arbitrarily. The arrest, detention or imprisonment of a child shall be in conformity with the law and shall be used only as a measure of last resort and for the shortest appropriate period of time" (IACHR, 2014, fn. 273).

20 "The Court has maintained, based on Article 5(5) of the American Convention and 37(c) of the Convention on the Rights of the Child, that children should be separated from adults, because holding them in the same place creates conditions that "are extremely prejudicial for their development and makes them vulnerable before third parties who, because they are adults, may abuse of their dominant situation" (IACHR, 2014, Para. 176; OAS, 1969; UN, 2004). 
And due to this understanding, regarding children that migrate to another nation illegally along with their parents/legal guardians/relatives, it should be noted the Court recognizes that everyone that accompanies them may be subject to the same beneficial interpretation, meaning that for the protection of family, no one linked to a child migrant should be incarcerated for illegally crossing State borders or for there staying, even as a last resort. This reasoning derives from the protection of family rights and its concurrent prohibition of arbitrary or abusive interference in family life, prescribed by article 19 of the American Convention of Human Rights21.

The Court stated that such article "should be understood as an additional, supplementary right that the treaty establishes for individuals that, owing to their physical and emotional development, require special protection" (IACHR, 2014, Para. 66). In other words, because of the said article, besides the obligation States have to safeguard children's rights, they poses an additional duty so as "to ensure that the society and the family adopt the measures of protection that all children require from them", as not only countries must protect the children within their territorial and personal jurisdiction 22 , but also the corresponding family and society. 23

This means that "the State should enable and guarantee these relationships" (IACHR, 2014, Para. 67). After all, "the primary responsibility for the care and development of the child corresponds to the parents and, subsidiarily, the State" (IACHR, 2014, Para. 156). In this sense, countries must "ensure the child [has] such protection and care as [it] is necessary for her or his wellbeing, taking into account the rights and duties of her or his parents, legal guardians, or other individuals legally responsible for him or her" (IACHR, 2014, Para. 156), which could amount to the impossibility of family separation at the border or even their incarceration, as the Court affirmed:

When the child's best interest requires keeping the family together, the imperative requirement not to deprive the child of liberty extends to her or his parents and obliges the authorities to choose alternative measures to detention for the family, which are appropriate to the needs of the children. Evidently, this entails a correlative State obligation to design, adopt and implement alternative measures to closed detention centers in order to preserve and maintain the family unit and to promote the protection of the family without imposing an excessive sacrifice on the rights of the child by the deprivation of liberty of all or part of the family (IACHR, 2014, Para. 158).

By all means, falls within a country's obligation "in the case of migrant children,

21 Article 19. Rights of the Child Every minor child has the right to the measures of protection required by his condition as a minor on the part of his family, society, and the State (IACHR, 2014, fn. 67).

22 Territorial jurisdiction amounts to the power a "State holds the full and exclusive legal power granted to it by International Law over its entire territory, that is, all assets and all situations, activities and people who, for any cause or reason to enter, or are acting on it, thus assuming the necessary functions, whether executive, legislative or judicial, for the sake of organizing the community enters, lives, or operates within it". On the other hand, personal jurisdiction of a State refers to the exercise of "authority over its nationals who are abroad, regulating personal status and exerting its protection over them" (IACHR, 2014, fns. 75-76).

23 "[T]he measures of protection that the child requires, owing to its condition as such and that are adopted by the State may be, in themselves, insufficient and must, therefore, be complementary to those that society and the family must adopt. From this point of view, the statute of the child is not limited to the sphere of its relationship with the State, but rather it extends to the relationship that it has or should have with her or his family and with society as a whole" (IACHR, 2014, Para. 67). 
[to] ensure that adults are not using them for their own migratory purposes and that if, despite everything, this should occur, that the children do not end up prejudiced" (IACHR, 2014, Para. 67). Nonetheless, if it is not the case, "States can and should have other less harmful alternatives" (IACHR, 2014, Para. 160).

\section{THIRD MAXIM OF THE LATIN-AMERICAN CHILD MIGRATION LAW: THE NON-REFOULEMENT PRINCIPLE}

Non-refoulement refers to the obligation States have not to return, expel or extradite anyone "to the frontiers of territories where his life or freedom would be threatened on account of his race, religion, nationality, membership of a particular social group or political opinion" (IACHR, 2014, Para. 209). It is internationally prescribed by article 33(1) of the 1951 Geneva Convention relating to the Status of Refugees (UN, 1954). However, as it constitutes a norm of customary international law, "[it] is, consequently, binding for all States, whether or not they are parties to the 1951 Convention or its 1967 Protocol" (IACHR, 2014, Para. 211).

Besides, as a general rule of international human rights law, it is not only applicable to refugees, but to any person that might be endangered if he or she leaves the territory of a State in direction to his or her country of origin (due to nationality or former domicile) or any third state24. In Latin America, for instance, the non-refoulement principle is not explicitly prescribed by the documents of the Inter-American System, deriving "from the fundamental obligations to respect and ensure rights under Article 1(1) of the [American] Convention assumed in relation to each of the protected rights and, in this case, with regard to the right of everyone to seek and receive asylum" set "in Article XXVII of the American Declaration and then in Article 22(7) of the American Convention" (IACHR, 2014, Para. 212).

Furthermore, within Latin America, this principle has a broader sense, prescribing that

[...] States are bound not to return ("refouler") or expel a person - [any migrant 25 ] - to a State where her or his life or liberty may be threatened as a result of persecution for specific reasons or due to generalized violence, foreign aggression, internal conflicts, massive violations of human rights or other circumstances which have seriously disturbed public order, nor to a third State from which she or he may later be returned to the State where she or he suffered this risk - a situation that has been called 'indirect refoulement' (IACHR, 2014, Para. 212).

This means that anyone who might have its life endangered in another country may not be forcibly removed by a State and be sent out to it - even if the person has

24 "Article 22(8) of the American Convention establishes the prohibition to deport or return any "alien" to "a country, whether or not it is his country of origin" - in other words, to her or his country of nationality or, in the case of a stateless person, the country of habitual residence, or to a third State - in which "his right to life or personal freedom" are "in danger of being violated because of his race, nationality, religion, social status or political opinions." (IACHR, 2014, Para. 214).

25 "In the case of the Pacheco Tineo Family v. Bolivia, the Court had the opportunity to interpret this provision, and concluded that: "it may be considered that, under the Inter-American system, the right of any alien, and not only refugees or asylees, to non-refoulement is recognized, when his life, integrity and/or freedom are in danger of being violated, whatsoever his legal status or migratory situation in the country where he is" (IACHR, 2014, Para. 215). 
not effectively crossed the border, as migrants "may not be [summarily] rejected at the border or expelled without an adequate and individualized analysis of their requests" (IACHR, 2014, Para. 210). The only exception it allows is prescribed by article 33(2) of the before mentioned 1951 Geneva Convention (UN, 1954), which establishes that:

The benefit of the present provision may not, however, be claimed by a refugee whom there are reasonable grounds for regarding as a danger to the security of the country in which he is, or who, having been convicted by a final judgment of a particularly serious crime, constitutes a danger to the community of that country (IACHR, 2014, fn. 425).

In this sense, only if the migrant presents a great danger to the host country it shall refuse him or her. "However, such situations should be interpreted rigorously and restrictively", particularly "in relation to the obligations derived from non-derogable rights" as they do not offer any room for exceptions due to their rigid characteristic26 - not even under article 33(2) of the 1951 Geneva Convention (UN, 1954; IACHR, 2014, Para. 211).

And if such principle already "constitutes the cornerstone of the international protection of refugees and asylum seekers" (IACHR, 2014, Para. 209), when it comes to children's rights, it becomes even harder for a State to detract from it. On this issue, the Court made it clear that

[...] the obligation not to return them is not limited to the real danger that may exist for the child of irreparable harm to her or his rights, contemplated in Articles 6 and 37 of the Convention on the Rights of the Child, but also applies to other serious violations of the rights guaranteed by this instrument, such as "the insufficient provisions of food or health services," "whether [...] they originate from non-State actors or such violations are directly intended or are the indirect consequence of action or inaction" (IACHR, 2014, Para. 231).

This means that beside age and gender, whenever discussing the possibility of returning a child to the state of origin, countries should take into account "the logic established by the Convention on the Rights of the Child", which adds the obligation of States to "ensure to the maximum extent possible" the "adequate development and survival" of the child to the right to life framework, recognizing, thus, the need of "effective and interdependent guarantee[s] of [his or her] civil and political rights and the progressive full effectiveness of [his or her] economic, social and cultural rights" (IACHR, 2014, Para. 222).

Additionally, as stated the Court, the word 'development' should be interpreted "in a broad and holistic manner, to include the physical, mental, spiritual, moral, and social development", which are of "fundamental importance because children are at a crucial stage of their physical, mental, spiritual, moral, psychological and social development that will have an impact on the rest of their lives in one way or another" (IACHR, 2014, Para. 222).

In this regard, it is not possible to return a child "if it would lead to a reasonable risk [...] [of] result[ing] in the violation of fundamental human rights" broadly interpreted

26 For a definition of jus cogens norms, see article 53 of the 1969 Vienna Convention on the Law of Treaties (UN, 1980, p. 331-512); for a larger debate on its origins and normative character, see SQUEFF; ROSA, 2018, p. 124-138. 
(IACHR, 2014, Para. 231). Not only that, it is the view of the Court that such violations may even be considered cruel, inhuman and/or degrading - actions that intimately violate one's personal integrity as prescribed by article 5 of the American Convention of Human Rights27, which is considered a norm of a peremptory nature (ius cogens), and, thus, should be always avoided, making it impossible to execute the transferring of children under such circumstances (IACHR, 2014, Para. 224).

As a result, the only way that the return of a child migrant may occur is if it "is in the best interest of the child" (IACHR, 2014, Para. 231). And for that to happen it is essential that the competent authorities determine what they are before the measure is implemented, which can be done through interviews or by "giving her or him the opportunity to explain her or his reasons for not being returned, and make a prior or preliminary assessment in order to determine whether this risk exists. If the risk is verified, she or he should not be returned to her or his country of origin" (IACHR, 2014, Para. 232).

This way, not only the State may gather the information needed to corroborate its actions, but would also provide

[...] the basic guarantees of due process that must be ensured to aliens in administrative proceedings related to an irregular migratory status, in expulsion or deportation proceedings, either for persons who have entered or remained in a country without complying with the requirements of the immigration laws, or those who are in the country legally, and in proceedings to determine refugee status (IACHR, 2014, Para. 230).

Nevertheless, whenever interviewing children, there are a set of basic procedural guarantees that must be followed by the State in order for due process to be considered properly provided in light of "the principles of the child's best interest and comprehensive protection", which include the following:

[...] that the interview is conducted in a language the child understands; that it should be child-centered, gender-sensitive, and guarantee the child's participation; that the analysis takes into account safety and possible family reunification; that the child's culture and any reluctance to speak in the presence of adults [...] is acknowledged; that an interpreter is provided if required; that adequate installations and highly qualified personnel are available for interviewing children; that legal assistance is provided if required; that clear and comprehensive information is provided on the child's rights and obligations and on the follow-up to the process (IACHR, 2014, Para. 85).

Besides those requisites, s such list as non-exhaustive, it should also be taken into account - but still not limited to - the psychological maturity of the individual, and not the physical appearance of the child, and the respect of his or her culture in general, including its identity, practices, values and customs (IACHR, 2014, Paras. 88 and 125). Otherwise, "[t]he Court considers that a flagrant violation of the basic guarantees of due process may result in the violation of the principle of non-refoulement" (IACHR, 2014, Para. 230).

27 Article 5. Right to Humane Treatment. [...] 2. No one shall be subjected to torture or to cruel, inhuman, or degrading punishment or treatment. All persons deprived of their liberty shall be treated with respect for the inherent dignity of the human person (IACHR, 2014, fn. 101; OAS, 1969). 


\section{FINAL REMARKS}

By exercising its advisory jurisdiction, the Inter-American Court of Human Rights has the full authority of setting important legal parameters based on the American Convention and other instruments within the region (IACHR, 2014, Para. 19). Such interpretations may lead OAS Member-States into the right path of action, pointing to the ultimate protection of human rights of those under its jurisdiction. Moreover, considering the crescent dialogue between international courts 28 , particularly those concerning human rights, the establishment of legal parameters is increasingly important as one region may face recurrent situations that outnumber those happening in other locations, creating leading interpretations that may help solve similar problems.

This is the case of child migrants - a situation that has been increasing in the last few years and that pose a problem to the application of "regular" international law that is their vulnerable status, demanding specific rules and/or interpretations that perceive such specificity. And because there is no international treaty that specifically regulates the treatment to child migrants, but only for children (the 1989 International Convention on the Rights of the Child [UN, 2004]) or for refugees (the 1951 Geneva Convention relating to the Status of Refugees [UN, 1954]), the 2014 Advisory Opinion 'OC 21' delivered by the Inter-American Court of Human Rights is very significant.

By highlighting a set of basic principles applicable to child migration, the Court pointed out how OAS Member-States shall act when processing those minors that seek asylum within its boundaries. Divided in three maxims and interpreted in light of the vulnerability of children, (i) the right to seek and be granted asylum, (ii) the principles of non-criminalization and non-detention, and (iii) the non-refoulement principle guide the conduct of States in a way so far unseen in international law, leading to the conclusion that there is, indeed, a Latin American child migration law.

28 For larger explanation on the existence and content of such dialogue, see SLAUGHTER, 2004, p. 65-71; and BURKE-WHITE, 2002. 


\section{REFERENCES}

ARNOLD, Amanda. Family separation policy: What to know about the detention centers for immigrant children along the U.S.-Mexico Border. Published on Jun. 212018. Available at: https://www.thecut.com/2018/06/immigrant-children-detention-center-separated-parents.html. Accessed on: Jan. 15, 2019.

ARRIAGA, Felicia. Understanding Crimmigration: Implications for Racial and Ethnic Minorities Within the United States. Sociology Compass, v. 10, n. 9, pp. 805-812, 2016.

BBC. US child migrants: 2,000 separated from families in six weeks. Published on Jun. 15 2018. Available at: https://www.bbc.com/news/world-us-canada-44503318. Accessed on: Jan. 15, 2019.

BURKE-WHITE, William W. A community of courts: toward a system of international criminal law enforcement. Michigan international Law Journal, v. 21, n. 1, pp. 1-103, 2002.

DEMBOUR, Marie-Benedicte. When Humans Become Migrants. Oxford: Oxford University Press, 2015.

GROSFOGUEL, Ramón. Colonial difference, geopolitics of knowledge, and global coloniality in the modern/colonial capitalist world-system. Review (Fernand Braudel Center), v. 25, n. 3, pp. 203-224, 2002.

IACHR. Advisory Opinion OC-21/14. Published on Aug. 19 2014. Available at: www. corteidh.or.cr/docs/opiniones/serie a_21_eng.pdf. Accessed on: Jan. 15, 2019.

IACmHR. Human rights situation of refugee and migrant families and unaccompanied children in the United States of America. OAS/Ser.L/V/II.155 - Doc. 16. Published on Jul. 24 2015. Available at: <https://www.oas.org/en/iachr/reports/pdfs/refugees-migrants-us.docx>. Accessed on: Jan. 15, 2019.

OAS. American Delcaration of Human Rights. 1948. Available at: https://www.cidh.oas. org/basicos/portugues/b.Declaracao_Americana.htm. Accessed on: jan. 152019.

OAS. American Convention of Human Rights. 1969. Available inat https://www.cidh. oas.org/basicos/portugues/c.convencao_americana.htm. Accessed on: jan. 152019.

OAS. Cartagena Declaration on Refugees, Colloquium on the International Protection of Refugees in Central America, Mexico and Panama. 1984. Available at: https://www. oas.org/dil/1984_cartagena_declaration_on_refugees.pdf. Accessed on: jan. 152019.

ROSENBLUM, Marc R. Unaccompanied Child Migration to the United States: The Tension between Protection and Prevention. Published on Apr. 2015. Available at: https://www.migrationpolicy.org/research/unaccompanied-child-migration-united-states-tension-between-protection-and-prevention. Accessed on: jan. 152019.

SHINKMAN, Paul D. Comparing the Policies and Practices of Detaining Children. 
Published on Jun. 15 2018. Available at: https://www.usnews.com/news/best-countries/ articles/2018-06-25/how-other-countries-treatment-of-detained-migrant-childrencompare-to-the-us. Accessed on: jan. 152019.

SLAUGHTER, Anne-Marie. A new world order. Princeton/NJ: Princeton University Press, 2004.

SQUEFF, Tatiana de A. F. R. Cardoso ; ROSA, Marina de A . Jus Cogens: an european concept? An emancipatory coneptual review from the Inter-American System of Human Rights. Revista de Direito Internacional, v. 15, n. 1, pp. 124-138, 2018.

STUMPF, Juliet. The The Crimmigration Crisis: Immigrants, Crime, and Sovereign Power. American University Law Review, v. 56, n. 2, pp. 367-419, 2006.

UN. 1951 Geneva Convention relating to the Status of Refugees. Recueil des Traités, v. 189, pp. 137-222, 1954.

UN. 1969 Vienna Convention on the Law of Treaties. Recueil des Traités, v. 1155, pp. 331-512, 1980.

UN. 1989 Convention on the Rights of the Child. Recueil des Traités, v. 2230, pp. 293296, 2004. 